\title{
Glycoconjugate Nanoribbons from Self-Assembly of Carbohydrate-Peptide Block Molecules for Controllable Bacterial Cell Cluster Formation
}

\author{
Yong-beom Lim ${ }^{\dagger}$, Somi Park ${ }^{\dagger}$, Eunji Lee ${ }^{\dagger}$, Haemi Jeong ${ }^{\dagger}$, \\ Ja-Hyoung Ryu ${ }^{\dagger}$, Myeong Sup Lee ${ }^{\ddagger}$, and Myongsoo Lee ${ }^{\dagger *}$ \\ ${ }^{\dagger}$ Center for Supramolecular Nano-Assembly and Department of Chemistry, ${ }^{\star}$ Department of \\ Biochemistry, Yonsei University, Seoul 120-749, Korea
}

Movie 1. Time-lapse phase contrast microscopic image of E. coli ORN178 strain (control).

Movie 2. Time-lapse phase contrast microscopic image of $E$. coli ORN178 strain treated with GP1.

Movie 3. Time-lapse phase contrast microscopic image of E. coli ORN178 strain treated with GP2. 


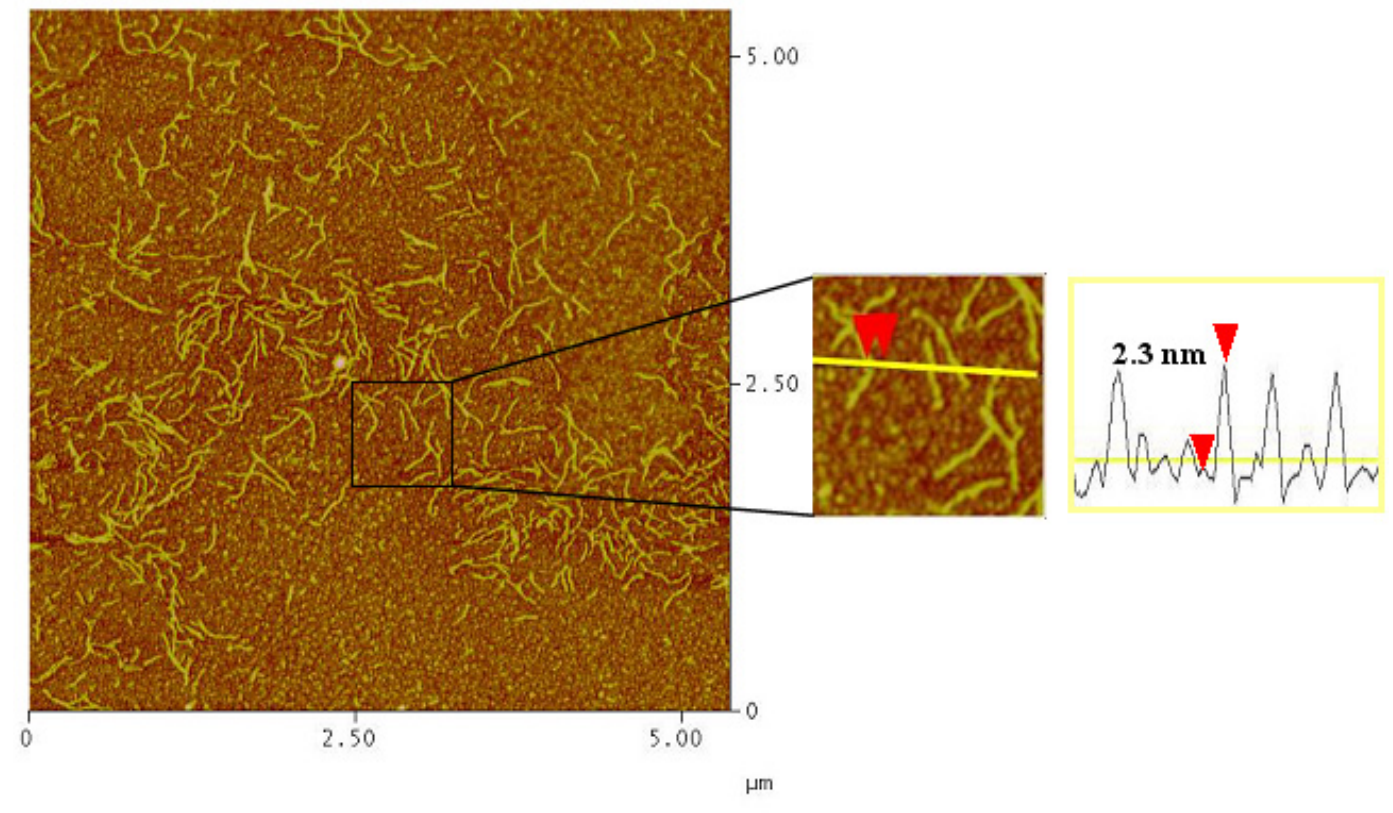

Figure S1. AFM image of GP2. The sample dissolved in water was deposited onto a freshly cleaved mica surface and dried in air. Inset shows the height information of GP2 nanoribbons. The images were obtained in tapping mode with setpoint $0.8-1 \mathrm{~V}$ and scanning speed 1-2 Hz. 

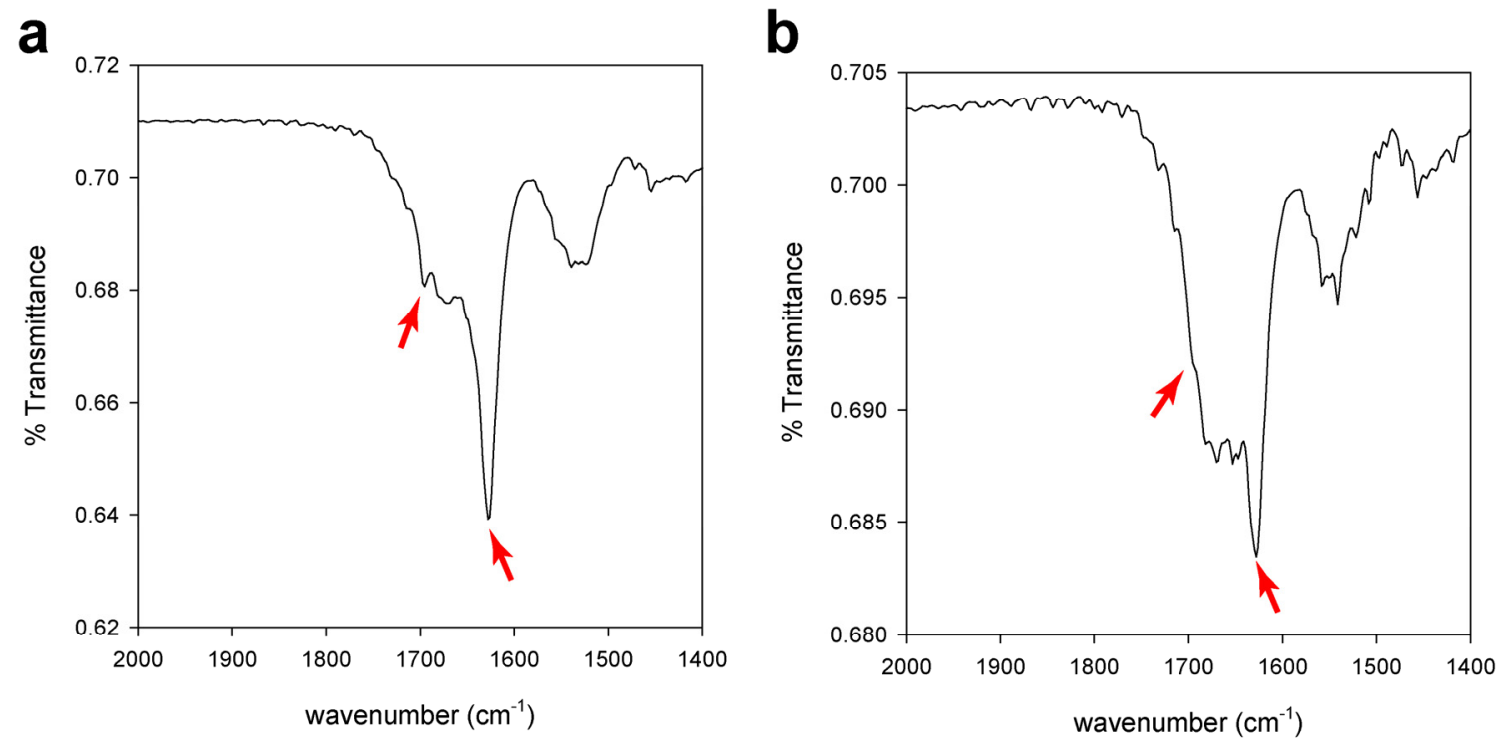

Figure S2. IR spectra of (a) GP1 and (b) GP2. The molecules were cast from water solution onto ZnSe window. The red arrows indicate peaks at 1695 and $1625 \mathrm{~cm}^{-1}$, which are characteristics of antiparallel $\beta$-sheet. ${ }^{[1,2]}$
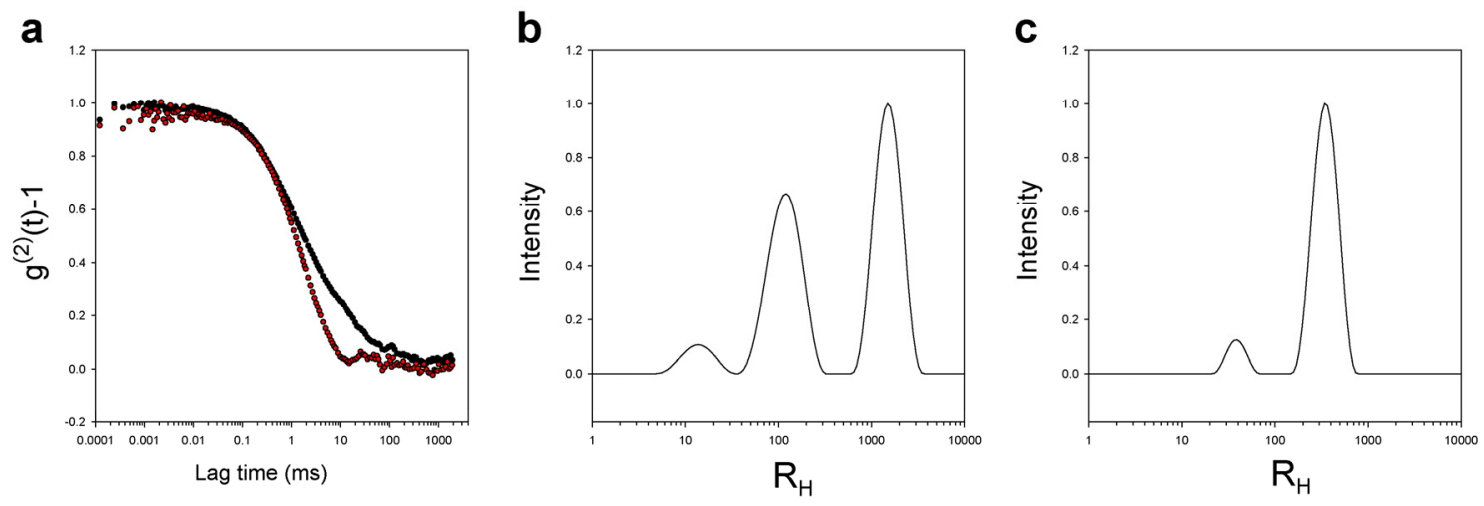

Figure S3. Dynamic light scattering data. (a) Autocorrelation function of GP1 (black) and GP2 (red). The sharp decrease in the autocorrelation function indicates that GP2 forms smaller particle than GP1 in solution. (b) CONTIN analysis of the autocorrelation function of GP1. (c) CONTIN analysis of the autocorrelation function of GP2. The CONTIN analyses revealed that GP2 forms smaller particles than GP1 in solution. The scattering angle was $90^{\circ}$ and the concentration was $50 \mu \mathrm{M}$ in water. 


\section{Measurements}

${ }^{1} \mathrm{H}$ and ${ }^{13} \mathrm{C}$ NMR spectra were recorded on a Bruker AM 250 spectrometer. Dynamic light scattering experiment performed with ALV/CGS-3 Compact Goniometer System equipped with He-Ne laser operating at $632.8 \mathrm{~nm}$. IR measurement was done in Bruker equinox 55 spectrometer. CD spectra were measured using a JASCO model J-810 spectropolarimeter. MALDI-TOF MS was performed on a Applied Biosystems Voyager-DE STR Biospectrometry Workstation using $\alpha$-cyano-4-hydroxycinnamic acid (CHCA) as a matrix.

\section{Synthesis}
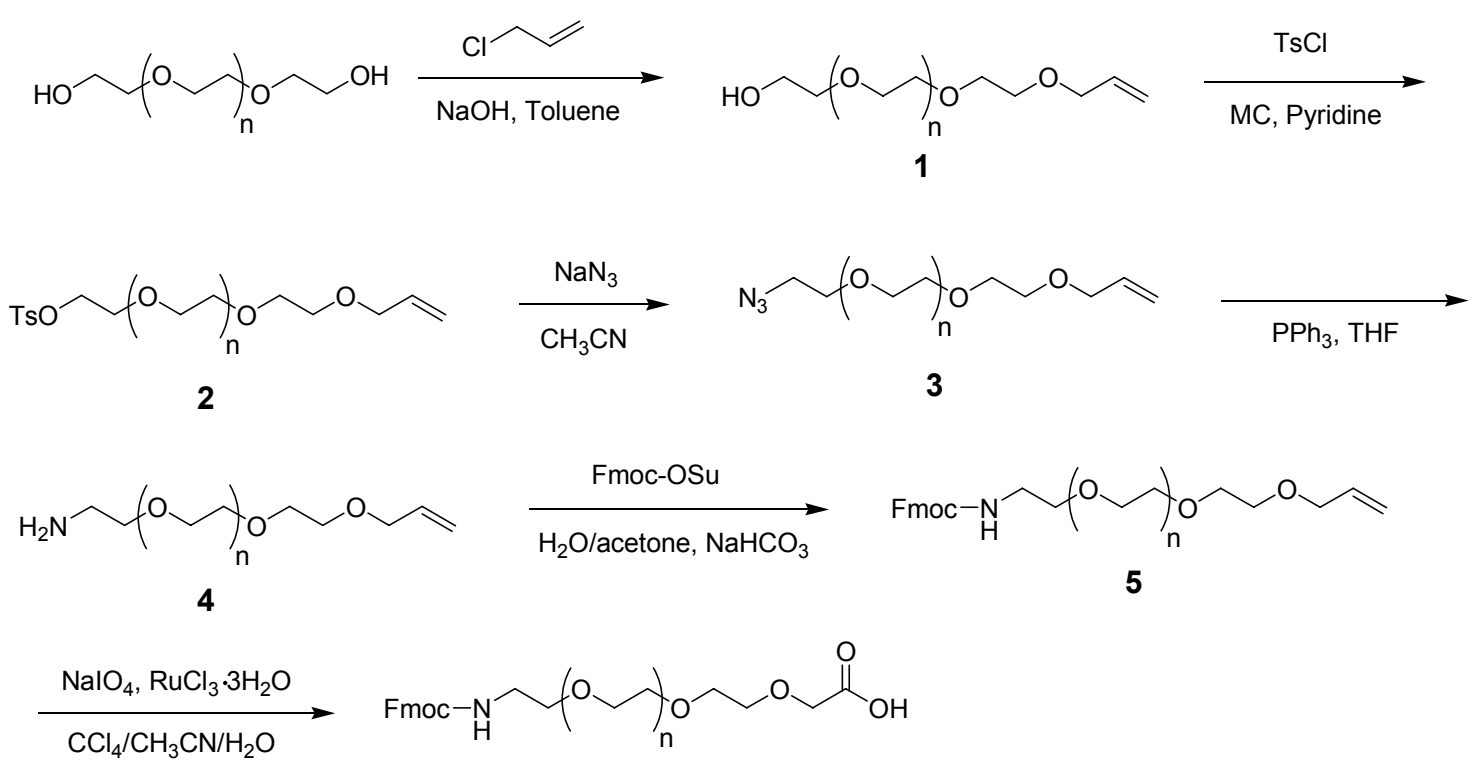

6,7

Scheme 1. Synthesis of Fmoc-NH-TEG-COOH and Fmoc-NH-(PEG) $)_{n}-\mathrm{COOH}(\mathrm{n}=5-7)$.

\section{Synthesis of compound 1.}

To a solution of triethylene glycol (TEG, $30 \mathrm{~g}, 200 \mathrm{mmol})$ in toluene $(180 \mathrm{~mL})$ was added allyl chloride $(16.4 \mathrm{~mL}, 200 \mathrm{mmol})$ and excess $\mathrm{NaOH}$. The mixture was reacted overnight under reflux and evaporated to dryness in vacuo. The resulting residue was dissolved in ethyl acetate and washed with water. The crude product was purified by column chromatography to yield $15 \mathrm{~g}(39.5 \%)$ of 1 as light 
yellow oil. ${ }^{1} \mathrm{H}-\mathrm{NMR}\left(250 \mathrm{MHz}, \mathrm{CDCl}_{3}, \mathrm{ppm}\right): \delta=6.01-5.84\left(\mathrm{~m}, 1 \mathrm{H}, \mathrm{CHCH}_{2}\right), 5.29-5.14(\mathrm{~m}, 2 \mathrm{H}$, $\left.\mathrm{CHCH}_{2}\right), 4.00\left(\mathrm{~d}, 2 \mathrm{H}, \mathrm{OCH}_{2} \mathrm{CH}\right), 3.69-3.58\left(\mathrm{~m}, 12 \mathrm{H}, \mathrm{CH}_{2} \mathrm{CH}_{2} \mathrm{O}\right), 2.66(\mathrm{~s}, 1 \mathrm{H}, \mathrm{OH})$.

\section{Synthesis of compound 2.}

Compound 1 (15 g, $78.5 \mathrm{mmol}$ ) and Tosyl chloride (75 g, $392 \mathrm{mmol}$ ) were dissolved in methylene chloride $(60 \mathrm{~mL})$ and then pyridine $(64 \mathrm{~mL}, 784 \mathrm{mmol})$ was added slowly. After overnight reaction, excess pyridine was neutralized by $\mathrm{HCl}$, solvent evaporated, dissolved in methylene chloride, and washed with water. The crude product was purified by column chromatography to yield $7.5 \mathrm{~g}(30 \%)$ of 2 as light yellow oil. ${ }^{1} \mathrm{H}-\mathrm{NMR}\left(250 \mathrm{MHz}, \mathrm{CDCl}_{3}, \mathrm{ppm}\right): \delta=7.79$ (d, 2H, Ar- $\left.H\right), 7.33(\mathrm{~d}, 2 \mathrm{H}, \mathrm{Ar}-H)$, 5.89-5.84 (m, 1H, $\left.\mathrm{CHCH}_{2}\right), 5.30-5.18\left(\mathrm{~m}, 2 \mathrm{H}, \mathrm{CHCH}_{2}\right), 4.14\left(\mathrm{t}, 2 \mathrm{H}, \mathrm{SO}_{3} \mathrm{CH}_{2}\right), 4.01\left(\mathrm{~d}, 2 \mathrm{H}, \mathrm{OCH} \mathrm{H}_{2} \mathrm{CH}\right)$, 3.69-3.57 (m, 10H, $\left.\mathrm{CH}_{2} \mathrm{CH}_{2} \mathrm{O}\right), 2.44\left(\mathrm{~s}, 3 \mathrm{H}, \mathrm{CH}_{3}\right)$.

\section{Synthesis of compound 3.}

To a solution of compound $2(7.5 \mathrm{~g}, 23.4 \mathrm{mmol})$ in acetonitrile $(100 \mathrm{~mL})$ was added sodium azide $(12.2 \mathrm{~g}, 187.3 \mathrm{mmol})$ and the mixture was reacted for 4 days at $40{ }^{\circ} \mathrm{C}$. The reaction mixture was evaporated, dissolved in methylene chloride, and washed with water. The organic layer was dried over $\mathrm{MgSO}_{4}$ and evaporated to give $3.7 \mathrm{~g}(77 \%)$ of 3 as light yellow oil. ${ }^{1} \mathrm{H}-\mathrm{NMR}\left(250 \mathrm{MHz}, \mathrm{CDCl}_{3}, \mathrm{ppm}\right)$ : $\delta=5.93-5.86\left(\mathrm{~m}, 1 \mathrm{H}, \mathrm{CHCH}_{2}\right), 5.31-5.16\left(\mathrm{~m}, 2 \mathrm{H}, \mathrm{CHCH}_{2}\right), 4.03\left(\mathrm{~d}, 2 \mathrm{H}, \mathrm{OCH}_{2} \mathrm{CH}\right), 3.69-3.59(\mathrm{~m}, 10 \mathrm{H}$, $\left.\mathrm{CH}_{2} \mathrm{CH}_{2} \mathrm{O}\right), 3.39$ (t, 2H, N3CH2).

\section{Synthesis of compound 4.}

To a solution of compound $3(3.7 \mathrm{~g}, 18 \mathrm{mmol})$ in THF $(70 \mathrm{~mL})$ in ice bath was added triphenylphosphine $(5.2 \mathrm{~g}, 20 \mathrm{mmol})$. The mixture was slowly warmed to room temperature and reacted overnight. The triphenylphosphine was quenched by 1 equivalent of water and then solvents were evaporated, and redissolved in water. The aqueous solution was washed with toluene and evaporated to give $2 \mathrm{~g}(59 \%)$ of compound 4 as light yellow oil. ${ }^{1} \mathrm{H}-\mathrm{NMR}\left(250 \mathrm{MHz}, \mathrm{CDCl}_{3}, \mathrm{ppm}\right): \delta=5.90-5.84(\mathrm{~m}$, $\left.1 \mathrm{H}, \mathrm{CHCH}_{2}\right), 5.31-5.19\left(\mathrm{~m}, 2 \mathrm{H}, \mathrm{CHCH}_{2}\right), 4.02\left(\mathrm{~d}, 2 \mathrm{H}, \mathrm{OCH}_{2} \mathrm{CH}\right), 3.69-3.59\left(\mathrm{~m}, 10 \mathrm{H}, \mathrm{CH}_{2} \mathrm{CH}_{2} \mathrm{O}\right), 2.87$ (t, 2H, $\left.\mathrm{NH}_{2} \mathrm{CH}_{2}\right), 1.9$ (br, 2H, $\mathrm{NH}_{2}$ ). 


\section{Synthesis of compound 5.}

The compound of 4 (2 g, $10.6 \mathrm{mmol})$, Fmoc-OSu (3.6 g, $10.6 \mathrm{mmol})$, and $\mathrm{NaHCO}_{3}(1.2 \mathrm{~g}, 21.2$ mmol) were dissolved in water/acetone $(1: 1,100 \mathrm{~mL})$ and reacted overnight. The mixture was evaporated to dryness and purified by column chromatography yielding $2.84 \mathrm{~g}(65.3 \%)$ of 5 as light yellow oil. ${ }^{1} \mathrm{H}-\mathrm{NMR}\left(250 \mathrm{MHz}, \mathrm{CDCl}_{3}, \mathrm{ppm}\right): \delta=7.76(\mathrm{~d}, 2 \mathrm{H}, \mathrm{Ar}-H), 7.60$ (d, 2H, Ar- $\left.H\right), 7.40-7.31(\mathrm{~m}$, $4 \mathrm{H}, \mathrm{Ar}-\mathrm{H}), 5.89-5.83\left(\mathrm{~m}, 1 \mathrm{H}, \mathrm{CHCH}_{2}\right), 5.32-5.18\left(\mathrm{~m}, 2 \mathrm{H}, \mathrm{CHCH}_{2}\right), 4.39\left(\mathrm{~d}, 2 \mathrm{H}, \mathrm{CO}_{2} \mathrm{CH}_{2}\right), 4.21(\mathrm{t}, 1 \mathrm{H}$, $\left.\mathrm{CO}_{2} \mathrm{CH}_{2} \mathrm{CH}\right), 4.00\left(\mathrm{~d}, 2 \mathrm{H}, \mathrm{OCH}_{2} \mathrm{CH}\right), 3.67-3.60\left(\mathrm{~m}, 10 \mathrm{H}, \mathrm{CH}_{2} \mathrm{CH}_{2} \mathrm{O}\right), 3.39\left(\mathrm{t}, 2 \mathrm{H}, \mathrm{NHCH}_{2}\right)$.

\section{Synthesis of compound 6 (Fmoc-NH-TEG-COOH).}

$\mathrm{NaIO}_{4}(11.8 \mathrm{~g}, 55.2 \mathrm{mmol})$ and $\mathrm{RuCl}_{3} \bullet 3 \mathrm{H}_{2} \mathrm{O}(30 \mathrm{mg}, 0.15 \mathrm{mmol})$ were added to a stirred biphasic mixture of compound $5(2.84 \mathrm{~g}, 6.9 \mathrm{mmol}), \mathrm{CCl}_{4}(15 \mathrm{~mL})$, acetonitrile $(15 \mathrm{~mL})$, and water $(20 \mathrm{~mL})$. After overnight reaction at room temperature, the mixture was diluted with methylene chloride, washed with water, dried with $\mathrm{MgSO}_{4}$, and evaporated to dryness. The crude product was purified by column chromatography and then it was re-purified using preparative recycle gel permeation chromatography to yield $1.6 \mathrm{~g}(53 \%)$ of 6 as light yellow oil. ${ }^{1} \mathrm{H}-\mathrm{NMR}\left(250 \mathrm{MHz}, \mathrm{CDCl}_{3}, \mathrm{ppm}\right): \delta=7.75(\mathrm{~d}, 2 \mathrm{H}, \mathrm{Ar}-H)$, $7.59(\mathrm{~d}, 2 \mathrm{H}, \mathrm{Ar}-H), 7.39-7.31(\mathrm{~m}, 4 \mathrm{H}, \mathrm{Ar}-\mathrm{H}), 4.39\left(\mathrm{~d}, 2 \mathrm{H}, \mathrm{CO}_{2} \mathrm{CH}_{2}\right), 4.21\left(\mathrm{t}, 1 \mathrm{H}, \mathrm{CO}_{2} \mathrm{CH}_{2} \mathrm{CH}\right), 4.09(\mathrm{~s}$, $\left.2 \mathrm{H}, \mathrm{CH}_{2} \mathrm{CO}_{2}\right), 3.70-3.58\left(\mathrm{~m}, 10 \mathrm{H}, \mathrm{CH}_{2} \mathrm{CH}_{2} \mathrm{O}\right), 3.38\left(\mathrm{t}, 2 \mathrm{H}, \mathrm{NHCH}_{2}\right)$.

\section{Synthesis of compound 7 [Fmoc-(PEG)n-COOH, $n=5-7]$.}

Synthesis of the compound 7 was begun with polyethylene glycol $\left(\mathrm{M}_{\mathrm{n}}=300\right)$ instead of TEG, and all the synthetic procedures are the essentially same as those for the synthesis of $6 .{ }^{1} \mathrm{H}-\mathrm{NMR}(250 \mathrm{MHz}$, $\left.\mathrm{CDCl}_{3}, \mathrm{ppm}\right): \delta=7.75(\mathrm{~d}, 2 \mathrm{H}, \operatorname{Ar}-H), 7.60(\mathrm{~d}, 2 \mathrm{H}, \operatorname{Ar}-H), 7.41-7.30(\mathrm{~m}, 4 \mathrm{H}, \mathrm{Ar}-H), 4.40(\mathrm{~d}, 2 \mathrm{H}$, $\left.\mathrm{CO}_{2} \mathrm{CH}_{2}\right), 4.20\left(\mathrm{t}, 1 \mathrm{H}, \mathrm{CO}_{2} \mathrm{CH}_{2} \mathrm{CH}\right), 4.09\left(\mathrm{~s}, 2 \mathrm{H}, \mathrm{CH}_{2} \mathrm{CO}_{2}\right), 3.65-3.54\left(\mathrm{~m}, 30 \mathrm{H}, \mathrm{CH}_{2} \mathrm{CH} \mathrm{H}_{2}\right), 3.39(\mathrm{t}, 2 \mathrm{H}$, $\mathrm{NHCH}_{2}$ ). 


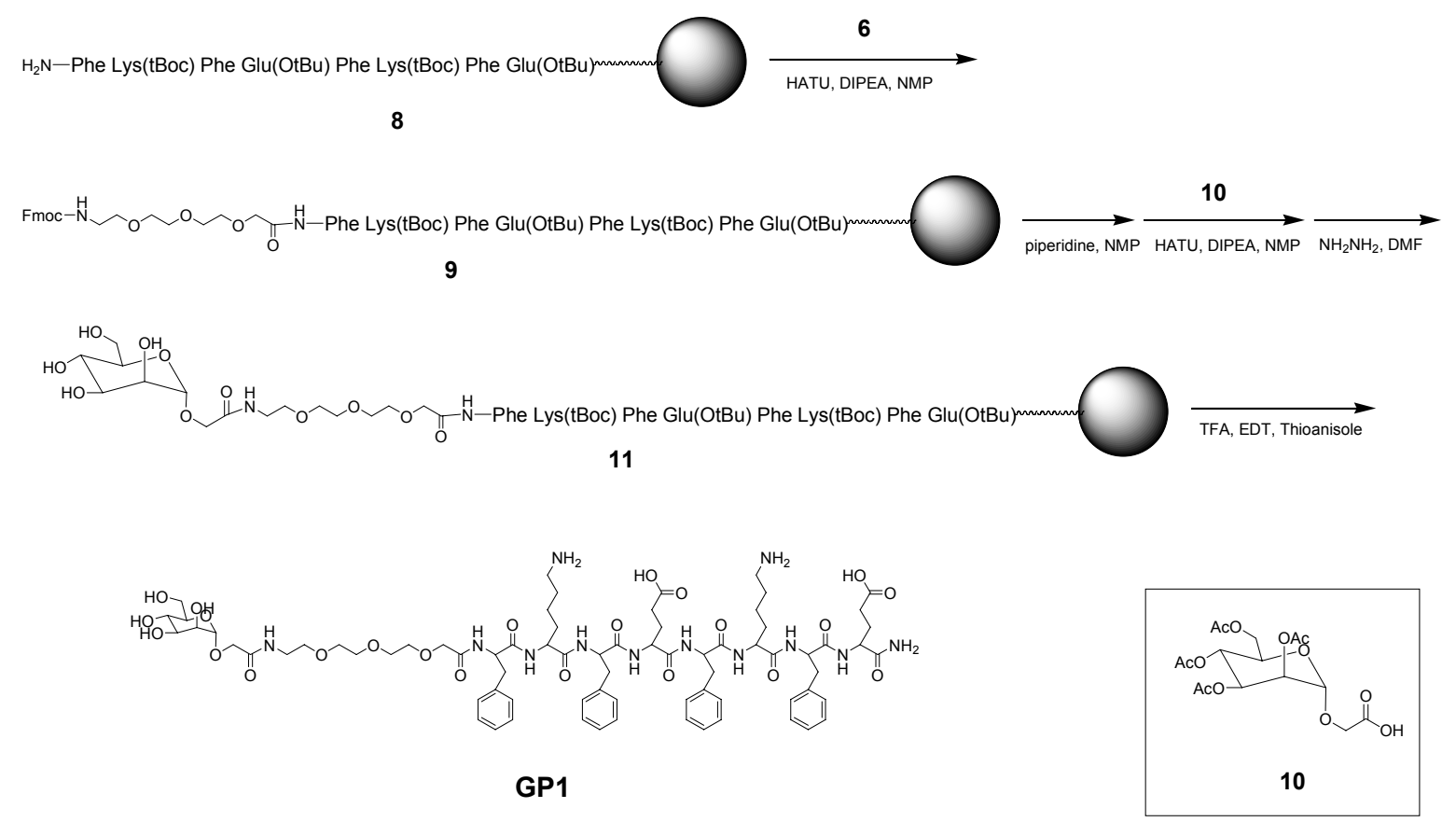

Scheme 2. Synthesis of GP1.

Synthesis of resin bound compound 8. The peptide was synthesized on Rink amide MBHA resin using standard Fmoc protocols with HATU activation protocols.

Synthesis of resin bound compound 11. To a resin bound peptide 8 (10 $\mu \mathrm{mol})$, compound 6 (20 $\mu$ mol), HATU $(20 \mu \mathrm{mol})$, DIPEA $(40 \mu \mathrm{mol})$, and NMP $(1 \mathrm{~mL})$ were added and reacted for $3 \mathrm{~h}$. The resin was then washed with DMF $(9 \times)$ and NMP $(1 \times)$. The resin was treated with 20\% piperidine in NMP for $1 \mathrm{~h}$ to deprotect Fmoc group. The resin washed and reacted with the compound $\mathbf{1 0}$ with the HATU activation protocol. Acetyl group from the compound was removed by the treatment of $10 \%$ hydrazine/DMF overnight yielding the resin bound compound $\mathbf{1 1 .}$

Synthesis of GP1. To a resin bound the compound 11 was added $1 \mathrm{~mL}$ of cleavage cocktail (TFA: EDT: thioanisole, 95: 2.5: 2.5) and reacted for $3 \mathrm{~h}$. The mixture was triturated with tert-butyl methyl ether, centrifuged, redissolved in water, and lyophilized. The compound was purified with reverse phase HPLC on C4 column using linear gradient of water/acetonitrile ( $0.1 \%$ TFA). The molecular weight of the compound was confirmed by MALDI-TOF MS. 


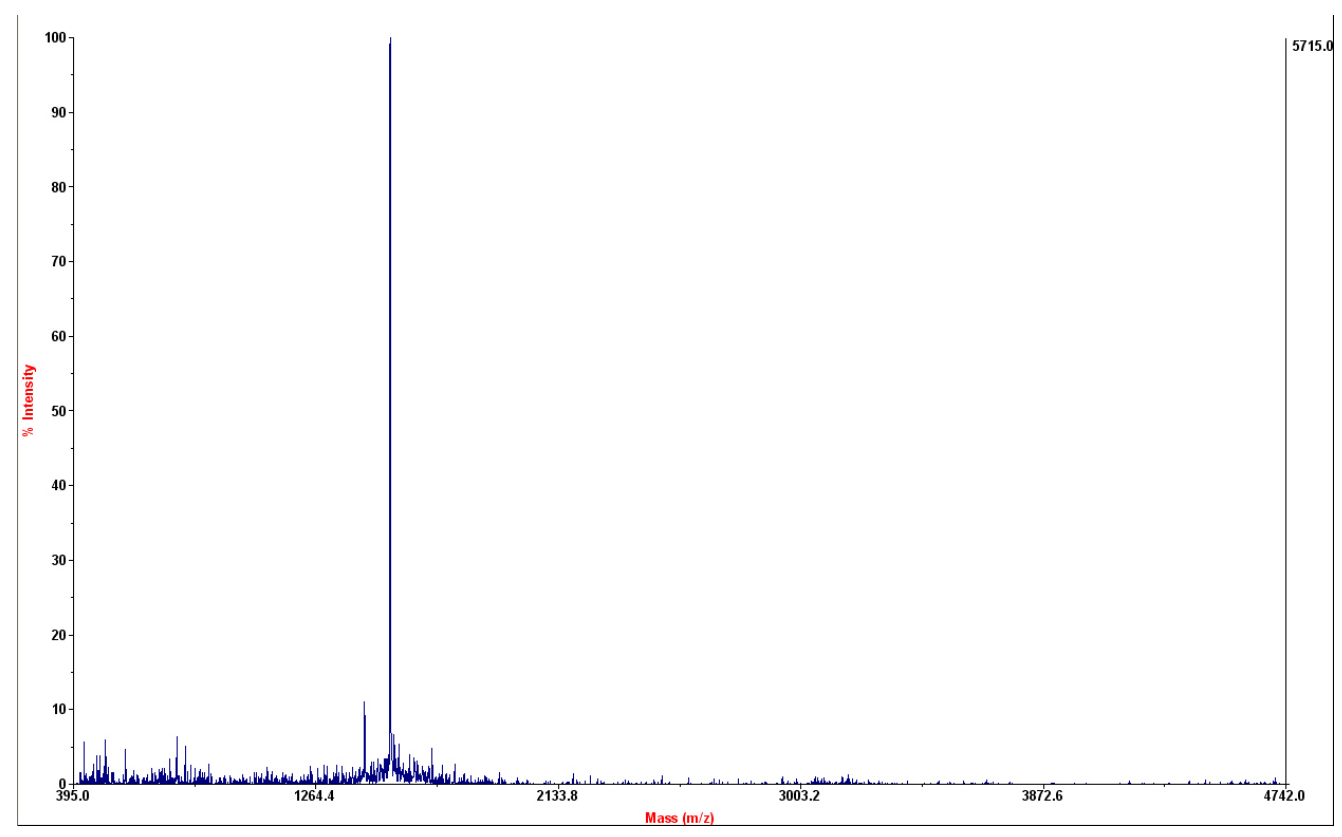

Figure S4. MALDI-TOF MS spectrum of GP1.

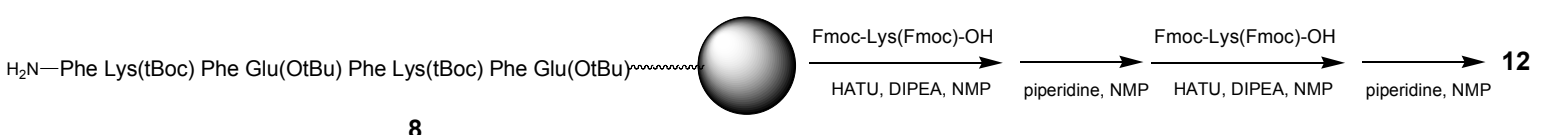
8
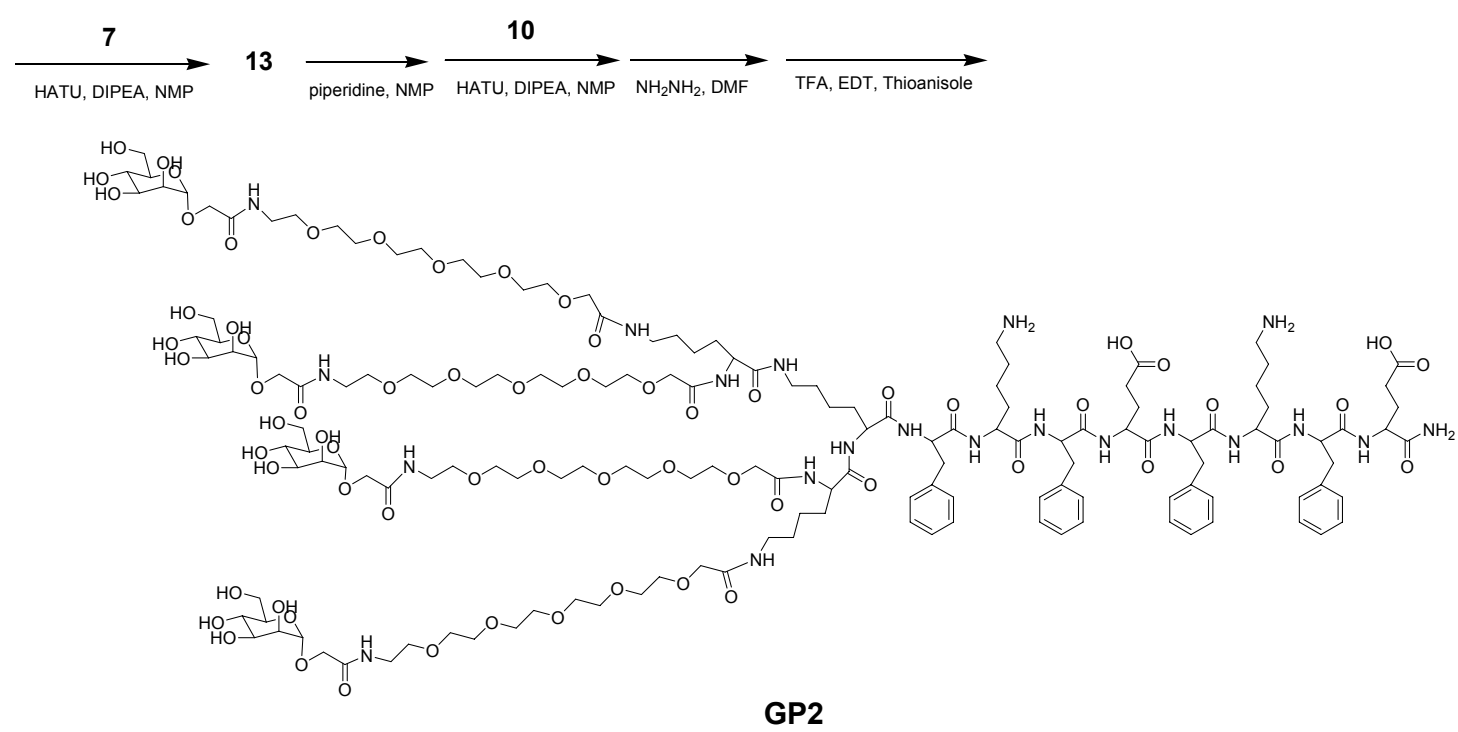

Scheme 2. Synthesis of GP2. 
Synthesis of GP2. To a resin bound peptide 8 (10 $\mu \mathrm{mol})$, Fmoc-Lys(Fmoc)-OH (20 $\mu \mathrm{mol})$, HATU (20 $\mu \mathrm{mol})$, DIPEA $(40 \mu \mathrm{mol})$, and NMP $(1 \mathrm{~mL})$ were added and reacted for $3 \mathrm{~h}$. The resin was then washed with DMF $(9 \times)$ and NMP $(1 \times)$. The resin was treated with $20 \%$ piperidine in NMP for $1 \mathrm{~h}$ to deprotect Fmoc group. The Lys(Fmoc)-OH reacted again to make dendritic molecule with 4 branches. The resin washed, reacted with the compound 7 with the HATU activation protocol, Fmoc removed, and coupled to the compound 10. Acetyl group from the compound was removed by the treatment of $10 \%$ hydrazine/DMF overnight. The compound was cleaved from the resin by the addition of $1 \mathrm{~mL}$ of cleavage cocktail (TFA: EDT: thioanisole, 95: 2.5: 2.5). The mixture was triturated with tert-butyl methyl ether, centrifuged, redissolved in water, and lyophilized. The compound was purified with reverse phase HPLC on C4 column using linear gradient of water/acetonitrile $(0.1 \%$ TFA $)$. The molecular weight of the compound was confirmed by MALDI-TOF MS.

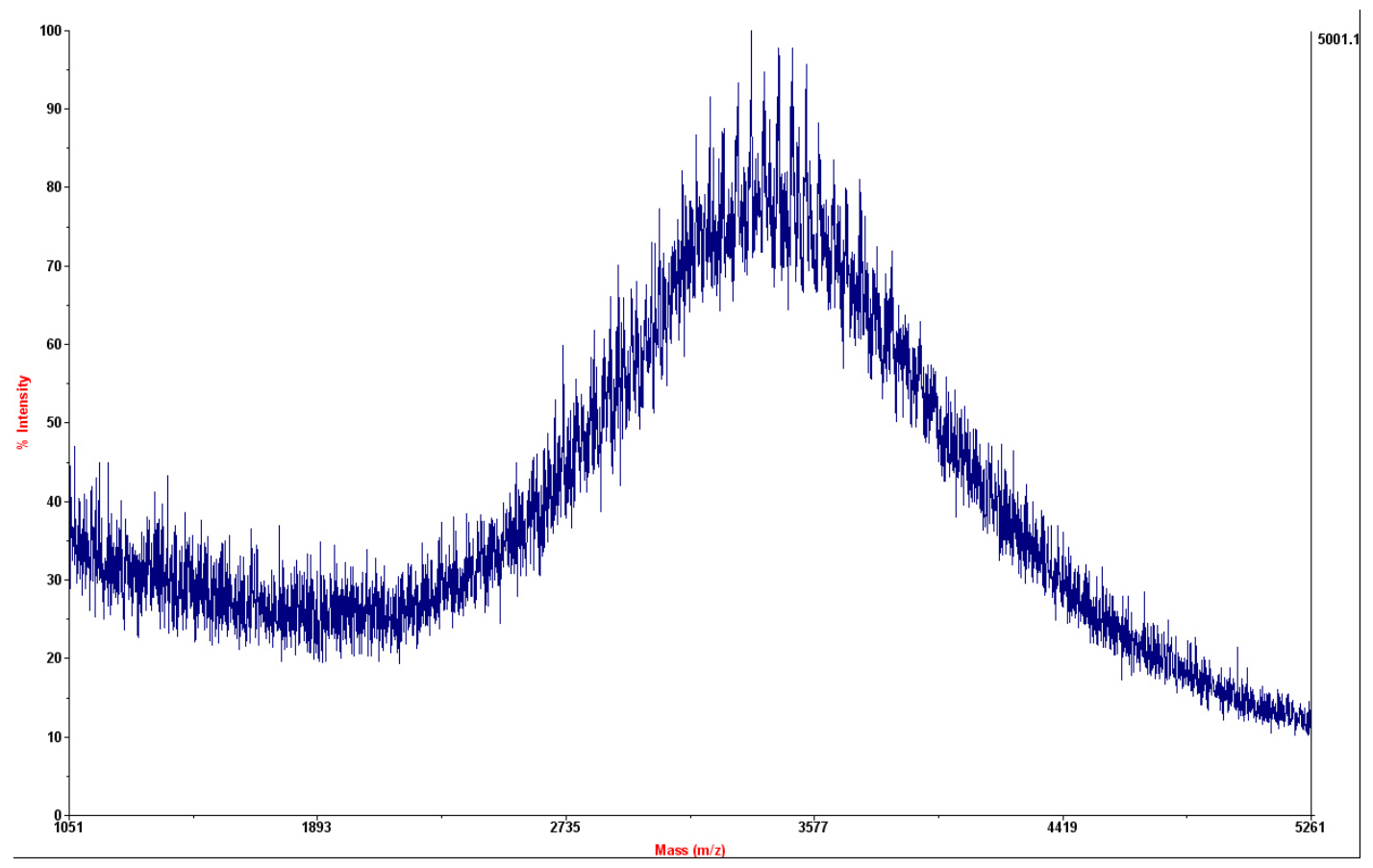

Figure S5. MALDI-TOF MS spectrum of GP2. 


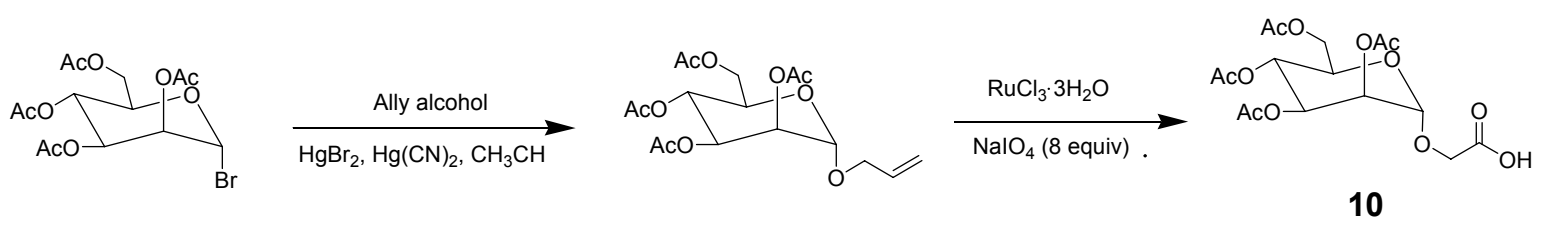

Scheme 3. Synthesis of 10.

\section{Synthesis of carboxymethyl 2,3,4,6-tetra- $O$-acetyl- $\alpha$-D-mannopyranoside (10).}

To a solution of bromo 2,3,4,6-tetra- $O$-acetyl-mannopyranoside $(5.7 \mathrm{~g} 12.0 \mathrm{mmol})$ in acetonitrile solution $(100 \mathrm{~mL})$ was added derierite $(10 \mathrm{~g})$, excess allyl alcohol (2.8 g, $48.2 \mathrm{mmol})$, mercury(II) bromide $(5.6 \mathrm{~g}, 12.0 \mathrm{mmol})$, and mercury(II) cyanide $(3.0 \mathrm{~g}, 12.0 \mathrm{mmol})$. The mixture was stirred overnight at room temperature and then filtered. The resulting residue was dissolved chloroform (200 $\mathrm{mL}$ ) and washed with brine. The organic layer was dried over anhydrous magnesium sulfate and filtered and concentrated. The crude product was purified by a flash column chromatography (silica gel, EtOAc/hexane $=1 / 1)$ to yield $3.3 \mathrm{~g}(60 \%)$ of allyl 2,3,4,6-tetra- $O$-acetyl- $\alpha$-D-mannopyranoside. ${ }^{1} \mathrm{H}$ $\operatorname{NMR}\left(250 \mathrm{MHz}, \mathrm{CDCl}_{3}, \mathrm{ppm}\right): \delta=6.05-5.84\left(\mathrm{~m}, 1 \mathrm{H}, \mathrm{OCH}_{2} \mathrm{CHCH}_{2}\right), 5.37-5.24\left(\mathrm{~m}, 5 \mathrm{H} ; \mathrm{OCH}_{2} \mathrm{CHCH}_{2}\right.$, H-2, H-3, H-4), 4.85 (d, $J=1.5$ Hz, 1H; H-1), 4.31- 3.95 (m, 5H; H-5, H-6, $\mathrm{OCH}_{2} \mathrm{CHCH}_{2}$ ), 2.05, 2.00, $1.94,1.91\left(\mathrm{~s}, 12 \mathrm{H} ; H_{3} \mathrm{CC}=\mathrm{O}\right)$.

Compound 10 was obtained by catalytic ruthenium trichloride oxidation of allyl 2,3,4,6-tetra- $O$ acetyl- $\alpha$-D-mannopyranoside. To a solution of allyl 2,3,4,6-tetra- $O$-acetyl- $\alpha$-D-mannopyranoside $(2.3 \mathrm{~g}$, $5.87 \mathrm{mmol})$ in a mixture of $\mathrm{CCl}_{4}(10 \mathrm{~mL}), \mathrm{CH}_{3} \mathrm{CN}(10 \mathrm{~mL})$, and $\mathrm{H}_{2} \mathrm{O}(15 \mathrm{~mL})$ was added $\mathrm{NaIO}_{4}(8.7 \mathrm{~g}$, $40.7 \mathrm{mmol})$. To this biphasic solution was added $\mathrm{RuCl}_{3} \cdot 3 \mathrm{H}_{2} \mathrm{O}(23 \mathrm{mg})$, and the resulting mixture was stirred vigorously for $6 \mathrm{~h}$ at room temperature. After dilution with $50 \mathrm{~mL}$ of $\mathrm{CH}_{2} \mathrm{Cl}_{2}$, the reaction mixture was filtered through a pad of Celite, and the phases were separated. The aqueous layer was extracted twice with $\mathrm{CH}_{2} \mathrm{Cl}_{2}$. The combined organic layer was washed with water and brine, dried over $\mathrm{MgSO}_{4}$, and concentrated. The crude product was purified by a flash column chromatography (silica gel, EtOAc/hexane $=1 / 1)$ to yield $1.9 \mathrm{~g}(80 \%)$ of $\mathbf{1 0} .{ }^{1} \mathrm{H}-\mathrm{NMR}\left(250 \mathrm{MHz}, \mathrm{CDCl}_{3}, \mathrm{ppm}\right): \delta=10.67(\mathrm{~s}, 1 \mathrm{H}$, $\mathrm{CH}_{2} \mathrm{COOH}$ ), 5.38-5.25 (m, 3H; H-2, H-3, H-4), 4.96 (d, J=1.5 Hz, 1H; H-1), 4.35- 4.09 (m, 5H; H-5, H6, $\left.\mathrm{OCH}_{2} \mathrm{COOH}\right), 2.05,2.00,1.94,1.91\left(\mathrm{~s}, 12 \mathrm{H} ; H_{3} \mathrm{CC}=\mathrm{O}\right)$. 


\section{References}

1. Matsuura, K.; Murasato, K.; and Kimizuka, N. J. Am. Chem. Soc. 2005, 127, 10148-9.

2. Dieudonne, D.; Gericke, A.; Flach, C. R.; Jiang, X.; Farid, R. S.; and Mendelsohn, R. J. Am. Chem. Soc. 1998, 120, 792-799. 